\title{
Comparing Coping strategies, happiness, hope for future in adolescent's survivor Bam earthquake with other adolescents
}

\author{
Elnaz Afshari ${ }^{1}$, Ahmad Zarei ${ }^{2}$, Mjid Mahmoud Alilou $^{3}$, Fatemeh Nemati ${ }^{4}$ \\ 1-Master of Child and Adolescent Clinical Psychology, University of Tabriz, Tabriz, Iran. ORCID: 0000-0002- \\ 4775-784X \\ 2-Master of Child and Adolescent Clinical Psychology, University of Tabriz, Tabriz, Iran. ORCID: 0000-0002- \\ 0408-3654 \\ E-mail: ahmad.hawar82@gmail.com \\ 3-Professor, University of Tabriz, Faculty of Education and Psychology, Tabriz, Iran. ORCID: 0000-0002-7690- \\ 196X \\ 4-Professor, University of Tabriz, Faculty of Education and Psychology,Tabriz, Iran. ORCID: 0000-0002-7151- \\ 2711
}

Received: 28/03/2018 Accepted: 09/09/2018

\begin{abstract}
Introduction: The earthquake is one of the largest and most devastating natural disasters, which has various physical and psychological effects on people, especially children and adolescents.

Aim: The aim of this study, was to compare the coping strategies, happiness and hope for the future in the adolescents survivor of Bam earthquake with normal adolescents.

Method: In this study 143 adolescents survivor of Bam earthquake and 207 normal adolescents were selected by multistage claster sampling and answered to Lazarus coping strategies, Oxford happiness and Snyder hope for the future. Data were analyzed by multivariate analysis of variance and $\mathrm{T}$ - independent group.
\end{abstract}

Result: Findings showed that survivors of earthquake use less problem-focused coping strategies and use more emotional-focused coping strategies, as well as happiness and hope for the future in them is lower than normal adolescents. Also, gender differences were observed in the studied variables.

Conclusion: Based on these findings, by providing appropriate psychological measures and training in coping strategies, the level of vulnerability of earthquake people can be significantly reduced.

Keywords: Coping Strategies, Happiness, Hope for the future, Survivors of Earthquake

How to cite this article: Afshari E, Zarei A, Alilou M M, Nemati F. Comparing Coping strategies, happiness, hope for future in adolescent's survivor Bam earthquake with other adolescents.. Shenakht Journal of Psychology and Psychiatry. 2018; 5 (3): $38-52$. URL :http://shenakht.muk.ac.ir/article-1-451-fa.pdf

Copyright (C) 2018 the Author (s). Published by Kurdistan University of Medical Sciences. This is an open access article distributed under the terms of the Creative Commons Attribution-Non Commercial License 4.0 (CCBY-NC), where it is permissible to download, share, remix, transform, and buildup the work provided it is properly cited. The work cannot be used commercially without permission from the journal. 


\title{
مقايسه راهبر دهاى مقابلهاى، شادكامى و اميد به آينده در نوجوانان بازمانده از زلزله بم با نوجوانان عادى
}

\author{
الناز افشارى'، احمد زارعى"، مجيد محمود عليلوّ، فاطمه نعمتى

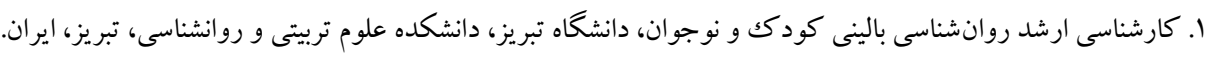

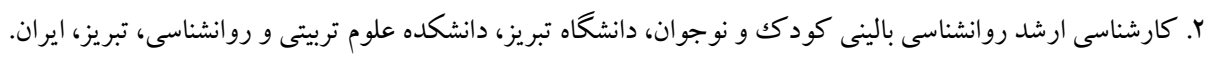 \\ ايميل: ahmad.hawar82@gmail.com

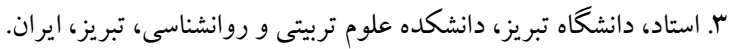

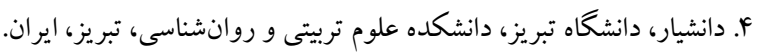

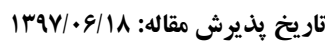

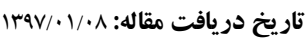

\section{جكيده}

مقدمه: زلزله ازجمله بزرك ترين و وير انغر ترين بلاياى طبيعى است كه اثرات جسمانى و روانشناختى مختلفى بر افراد جامعه به ويزه كود كان و نوجو انان مى خذارد.

هدف: لذا هدف اين يزوهش، مقايسهى راهبردهاى مقابلهاى، شادكامى و اميد به آينده در نوجوانان بازمانده از زلزلهى بم با نوجو انان عادى است.

روش: در اين يزوهش بعا نوجوان بازمانده از زلزله بم و V·r نفر از ساير نوجوانان به شيوه نمونه گيرى خوشهاى انتخاب شدند و

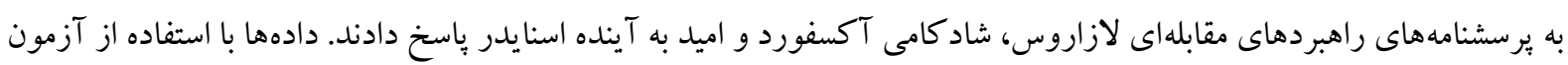
تحليل واريانس جندمتغيرى (MANOVA) و T كروههاى مستقل تحليل گرديد. يافتهها: يافتهاى بثزوهش نشان دادند كه نوجوانان بازمانده از زلزله از راهبردهاى مقابلهاى مسألهمدار كمتر و از راهبردهاى مقابلهاى هيجان مدار بيشتر استفاده مى كنند و ميزان شادكامى و اميد به آينده در اين افراد كمتر از نوجوانان عادى است. همجنين تفاوتهاى جنسيتى در متغيرهاى موردمطالعه مشاهده شد. نتيجه كيرى: بر اساس اين يافتها با انجام دادن اقدامات روانشناختى مناسب و آموزشهاى لازم در زمينه راهبردهاى مقابلهاى

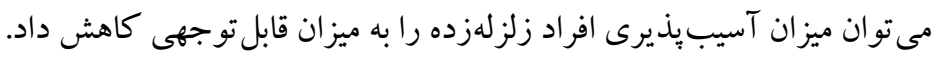
كليدوازه: راهبردهاى مقابلهاى، شاد كامى، اميد به آينده، بازمانده از زلزله 
منفى و توجه بيشتر به اطلاعات مثبت رابطه دارند مقدمه

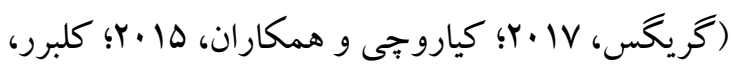

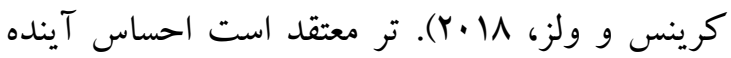
نداشتن در كودكان ضربه ديده به ويزه در اوايل نوجوانى وجود دارد و ممكن است مدت ها پِس از

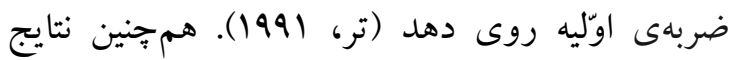
يثوهشهاى نجاريان و همكاران (IMV9) و سروش، حجازى و ازهاى (سوسا) نشان دادند كه روبرو شدن همن با فجايع، باعث افزايش نااميدى در افراد مىشود. به علاوه، بين دختران و بِران از نظر ميزان اميدوارى تفاوت معنادارى وجود دارد (كول و نظامى، ها •r؟؛

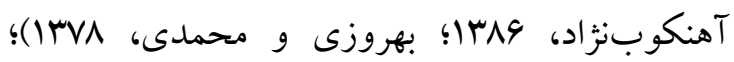
بنابراين مىتوان كفت داشتن اميد به آينده و روحيهى

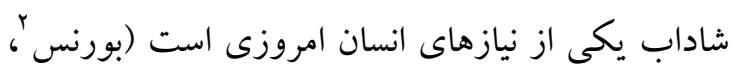

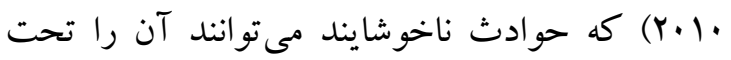
تأثير قرار بدهند. كالوو و همكاران (10/Y) نشان دادند كه ميزان شاد كامى افراد بعد از حوادث ناخوشايند طبيعى كاهش كان

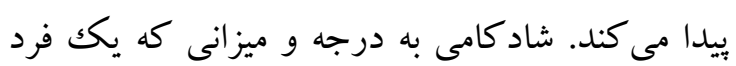
دربارهى مطلوبيت كيفيت كلى زندگىاش به به عنوان يكك كل قضاوت مى كند كفته مى شود، به عبارتى

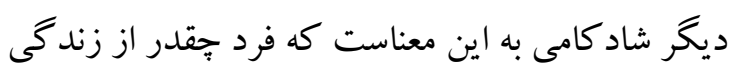
خود لذت مىبرد (ونهاون، צ. .ب؛ به نقل از زارع،

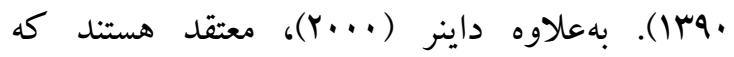
شادكامى، نوعى ارزشيابى است كه فرد از خود و و

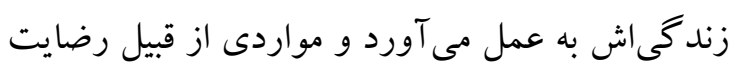

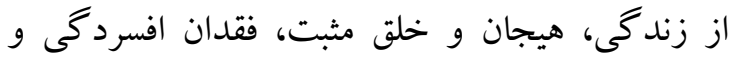
اضطر اب را شامل مىشود و جنبه هاى مختلف آن نيز به شكل شناختها و عواطف است (داينر، لو كاس و و وله

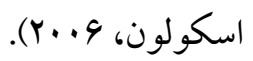

مو اجهه با حوادث و رخدادهاى ناخوشايند طبيعى مانند زلزله در دوران كودكى، زندگى فرد را تحت تأثير قرار خواهد داد و اثرات روانى و جسمانى متفاوتى خواهد داشت ازجمله احتمال بيمارىهاى حاد، كوتاهى قد و وزن كم را در كودكان زير ه سال افزايش مىدهد (داتار، ليو، لينماير و ستكر، با.بץ؛ لى و همكاران، - (Y.IV هاى استرس حاد، اختلال ساز كارى، افسردگى، اختلال استرس پِ از سانحه، اختلالات اضطرابى خاص در دوران كودكى و غيره را به دنبال خواهد داشت (بدريا،

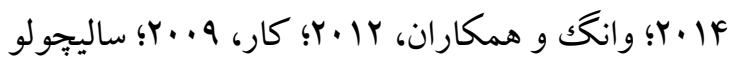

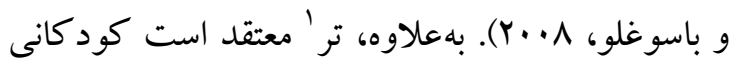
كه با تروما يا فجايع مواجه شدهاند در اوايل نوجوانى

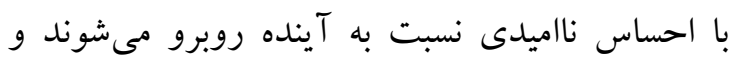
همجِنين به شكسته شدن راهبردهاى مقابلهاى در جريان آسيب اشاره مى كند (تر،199؛؛ به نقل از نجاريان و

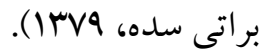
اميد به آينده به عنوان يكك عامل شناختى مى تواند افراد را درراه رسيدن به موفقيت يارى رساند. اسنايدر اميدوارى را بهعنوان ظرفيت يا قابليت ادراكى براى لئ ايجاد مسيرها و روشهاى مختلف براى رسيدن به

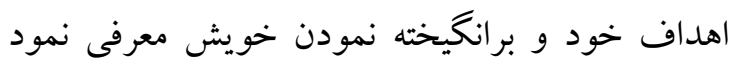

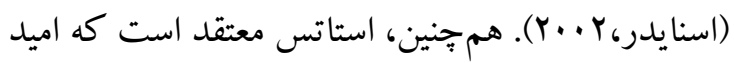
داراى دو مؤلفهى: شناختى و عاطفى هست كه مؤلفه عاطفى آن مىتواند بيشبينى كنندهى وقوع رويدادهاى مثبت در آينده و در نتيجه افزايش سلامت روان باشد

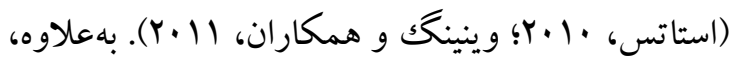
اميدوارى با مقابله مؤثر و بهزيستى بهتر رابطه دارد و

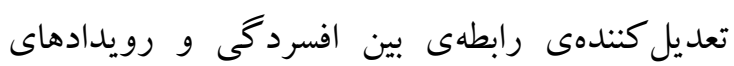
ناخوشايند زندگى است و با توجه كمتر به اطلاعات 


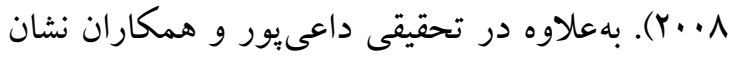
دادند كه نوجوانان يسر بيشتر از نوجوانان دختر از راهبردهاى مقابلهاى مراجعه به ديخران استفاده كردند درحالى كه دختران بيشتر از راهبردهاى مقابلهاى

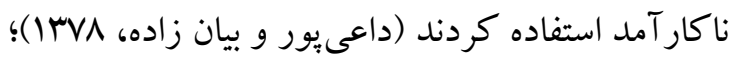
بنابراين يزوهشها نحوهى مقابله با حوادث آسيبزا مى تواند بر سلامت روانى فرد تأثير كذار باشد.

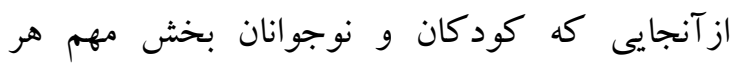
اجتماع به شمار مىروند انجام دادن تحقيقات و و هان بررسىهايى در مورد نيازها، تقاضاها و نحور نحونى

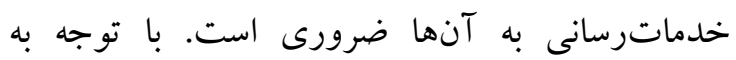
تأثيرات مخرب حوادث ناخوشايند طبيعى بر كود كان، داشتن اطلاعاتى در مورد مشكلات روانشناختى بعد از فجايع نه تنها بر دانش موجود مىافزايد بلكه مىتواند

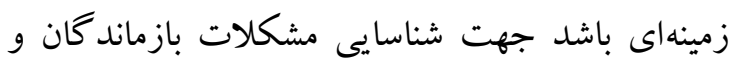
خدمترسانى مناسبتر به آنها. با توجه به بيشينهى

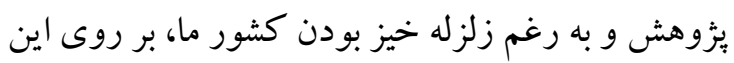

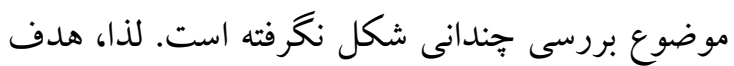
مطالعهى حاضر، مقايسهى راهبردهاى مقابلهاى، شاد كامى و اميد به آينده در نوجوانان بازمانده از زلزله ى بم با نو جوانان عادى است.

يثزوهش حاضر از نوع على-مقايسهاى است. جامعهى آمارى يزوهش حاضر، شامل كليهى نوجوانان شهرستان بم و شهرستان كرمان در فاصلهى سنى IV IV الت سال

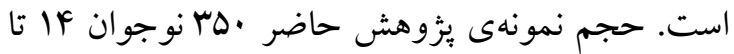
IV سال است كه سFا نفر از بم و V.r. نفر از كرمان انتخاب شدند. روش نمونه كيرى نيز به صورت خوشه اله اى جند مرحلهاى بود. به اين صورت كه ابتدا از دو

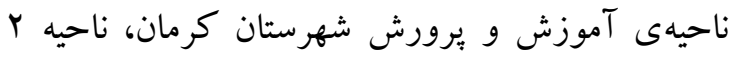

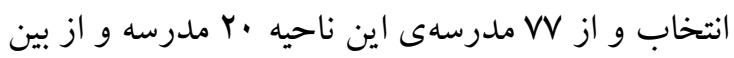

بهعلاوه افراد شاد در وجود خود احساس امنيت بيشترى مى كنند، آسانتر تصميم مى گيرند، داراى روحيهى مشاركتى بالاترى هستند و احساس رضايت آنها در زندگى بالاتر است (حسينى كسنويه، سليمى و و

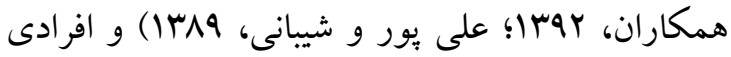
كه از شاد كامى مناسب برخوردار نمىباشند بيشتر مبتلا به افسردگى، اضطراب و ييامدهاى ناشى از آن بوده و در آنها اعتياد و رفتارهاى نابهنجار اجتماعى بيشتر ديده شده و از اميد به زندگى كمترى برخوردارند

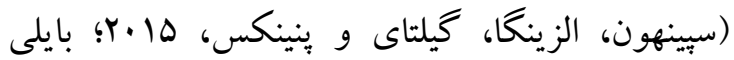
1991 و آركايل 1990؛ به نقل از حسينى كسنويه و همكاران، rrar). بهعلاوه شريفى و همكاران نشان دادند كه بين شاد كامى و تجربه حوادث استرسزا رابطه معنادارى وجود دارد ( شريفى، سوكى، تقربى و

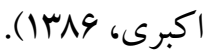
راهبردهاى مقابلهاى نقش مهمى را در تعديل يا كاهش

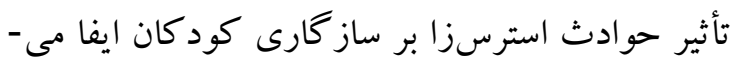

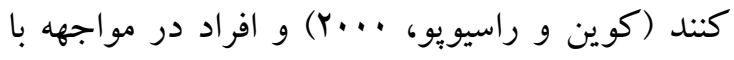
حوادث طبيعى از راهبردهاى متفاوتى استفاده مى كند

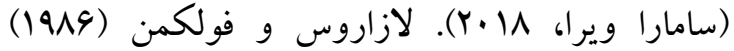
مقابله را جنين تعريف كردهاند: اتلاشهاى رفتارى و شناختى كه به طور مداوم در حال تغييرند تا از عهلدى نهي خواستهاى خاص بيرونى يا درونى شخص كه وراى منابع و توان وى ارزيابى مىشوند، برآيند) (به نقل از

هاشمى، عليلو، يورشريفى، بيرامى و نعمتى، بوسبا (I).

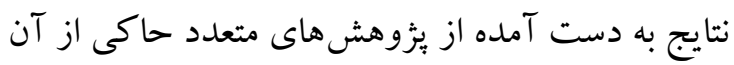
است افرادى كه منابع مقابلهى ضعيف و ناكار آمد در

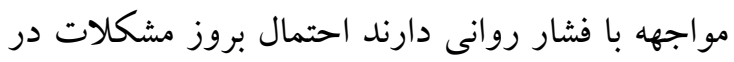
آنان بيشتر است (محمود عليلو، بخشى بور، اسماعيلى و طوفان، IrAV). و همجنين بعد از حوادث طبيعى ناخوشايند (طوفان) راهبردهاى مقابلهاى مثبت و منفى با شدت نشانگان PTSD رابطه داشتند (لاكك و ساليوان، 
به ترتيب • • • و و / • • به دست آمد كه اين امر نشانكر

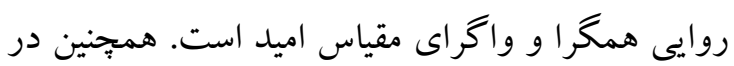

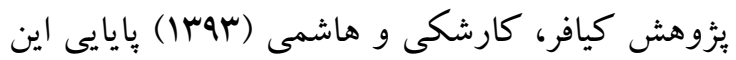

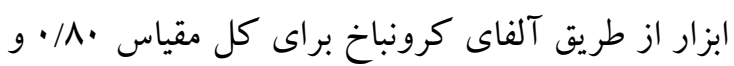
براى تفكر عامل VA/ • و تفكر راهبردى • •19/ • محاسبه شده است. آزمون شادكامى آكسفورد: برسشنامه شادكامى آكسفورد اولين بار توسط آركيل و لو (1919) تهيه

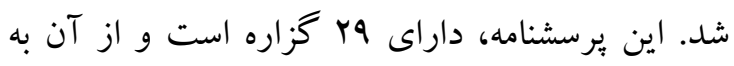
طور وسيع در انگلستان استفاده مىشود. وب سؤال اين

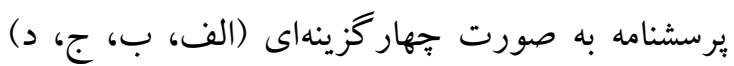

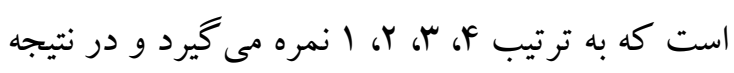
نمرهى نهايى بين · تا AV قرار مى گيرد. نجفى و و

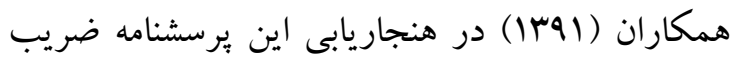

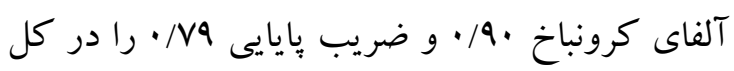
نمونه براى اين مقياس به دست آوردند. بهعلاوه، به منظور بررسى روايى همخرا و و واگراى برسشنامه،

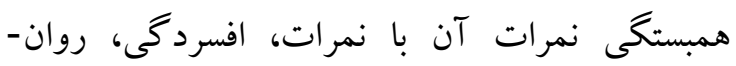

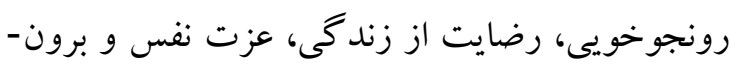
كرايى محاسبه كردند كه همبستكى آنها با شاد كامى رونى

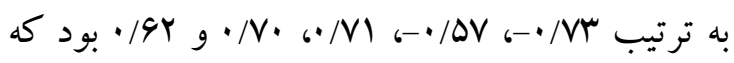

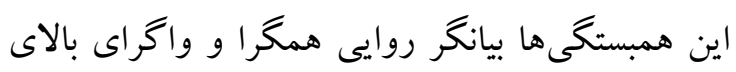
يرسشنامه است. مقياس روشهاى كنارآملن لازاروس: برسشنامهى

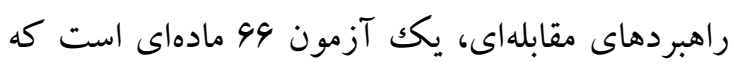
بر اساس سياهلى راهبردهاى مقابلهاى لازاروس و و فلكمن (·191) توسط لازاروس و فلكمن در سال 1919 ساخته شده است و دامنهى وسيعى از افكار و اعمالى كه افراد هنگام مواجهه با شرايط فشارزاى درونى يا بيرونى به كار مىبرند را مورد ارزيابى قرار

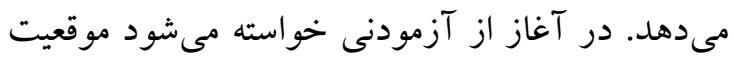

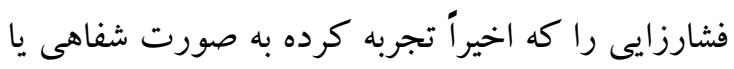

آنها • ا كلاس به صورت تصادفى انتخاب شد. در بم

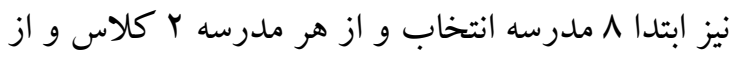
هر كلاس جند نفر به صورت تصادفى انتخاب شدند. لازم به ذكر است افرادى به عنوان نمونه انتخاب شدند كه در زمان وقوع زلزله r-ه سال سن داشتند و در شهرستان بم حضور داشتند، لذا افرادى كه ساكن بم هستند ولى در زمان وقوع زلزله در شهرستان بم حضور نداشتند در يزوهش از آنها به عنوان نمونه استفاده نشدهاست. مقياس اميدوارى: به منظور جمع آورى اطلاعات مربوط به اميد از برسشنامهى اميد اسنايدر (Y...

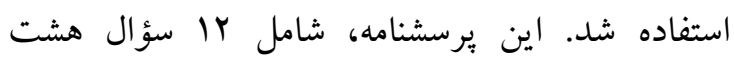

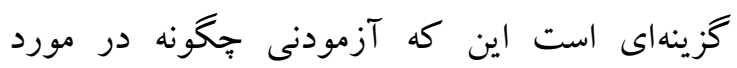
خودش فكر مى كند را از بين باسخهاى كاملاً موافقم تا

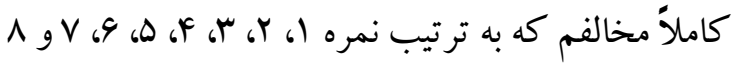

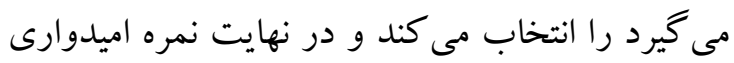

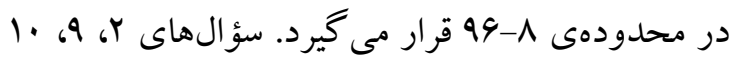

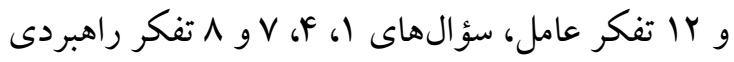
و سؤالهاى "، ها، و و لا نيز سؤالات انحرافى است. روايى و بايايى و همجنين بومىسازى اين برسشنامه در

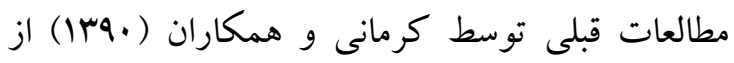
طريق تحليل عاملى تأييدشده است. در بيزوهش آنها اين گويهها و عوامل بو درصد از واريانس اميد را تبيين نمود. بهعلاوه، در ئزوهش آنها ضريب اعتبار اين مقياس با استفاده از فرمول آلفاى كرونباخ وه/، • و از طريق باز آزمايى |N/ • به دست آمده است. هم جنين در

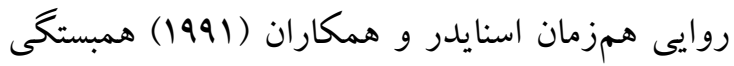

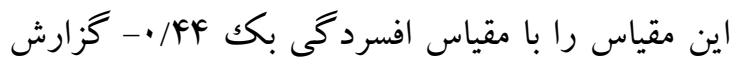

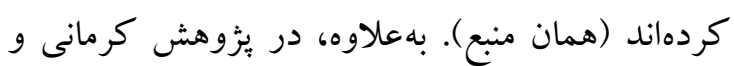

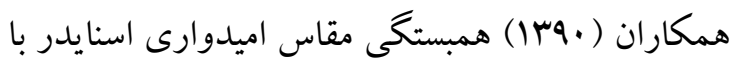

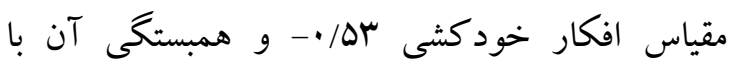
مقياس هاى حمايت اجتماعى ادراكتشده و معنا زندكى 
هاى مقابلهاى لازاروس اقدام شد. براى اين منظور

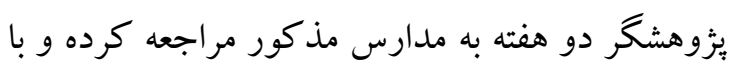
هماهنگى مسئولين و معلمان، اقدام به كردآورى اطلاعات از دانش آموزان نموده است. دادههاى حاصل از يُزوهش با استفاده از آزمون تحليل واريانس تجند متغيرى (MANOVA) و T Tروهاى مستقل تجزيه

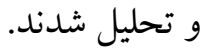

\section{يافتهها}

به منظور بررسى فرضيههاى بزوهش و تعيين معنادارى تفاوت ميان گروه نوجوانان بازمانده از زلزلهى بم با نوجوانان عادى در هر يكك از متغيرهاى يُزوهش از تحليل واريانس جند متغيره (MANOVA) استفاده شد. در رابطه با ويزگىهاى جمعيت شناختى افراد مورديزوهش قابلذكر است كه A.Aه/ درصد از

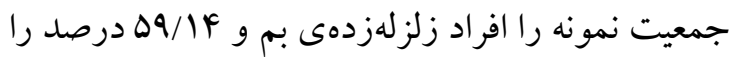
نوجوانان عادى تشكيل مىدهند و همجِين

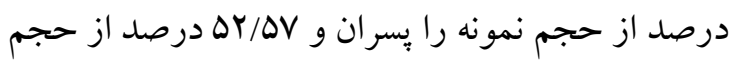
نمونه را دختران تشكيل مىدهند. بهعلاوه، يافتهاى توصيفى متغيرهاى بثزوهش در دو گروه مورد مطالعه در جدول-1 ارائه شدهاست.
نوشتارى شرح دهد سبس با خواندن عبارات برسشنامه مشخص كند كه در موقعيت مورد نظر تا جه ميزان از هريك از راهبردهاى زير استفاده كرده است. در برخى موارد، خود بثزوهشخر موقعيتى خاص مانند درمان بزشكى يا يكك آزمون علمى را به عنوان موقعيت فشارزا مشخص مى كند. آزمودنى به هر سؤال در مقياسهاى درجهاى ليكرت (هيج وقت= صفر، به ندرت= (ا، اغلب= Y و خيلى زياد=r) ياسخ مىدهد. اين آزمون داراى ^ زير مقياس مقابلهى مستقيم، فاصله كرفتن، خود كنترلى، طلب حمايت اجتماعى، بِيرش

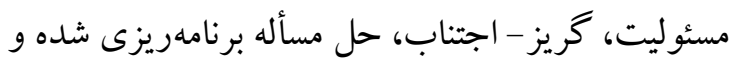
ارزيابى مجدد مثبت است لازاروس ضريب اعتبار باز آزمايى يا ثبات درونى را براى هريك از راهبردهاى مقابلهاى 199. تا V9/. كزارش كرده است. همجنين آلفاى كرونباخ براى راهبردهاى مقابلهاى هيجانمدار

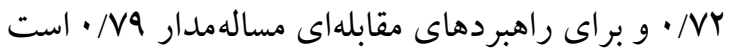

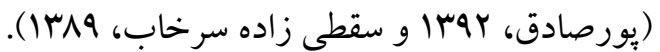
״س از كسب مجوز از آموزش و يُوورش شهرستان كرمان و بم، نمونهاى مورد نظر از بين دبيرستانها انتخاب و نسبت به تكميل و جمع آورى يرسشنامههاى اميد به آيندهى اسنايدر، شاد كامى آكسفورد و راهبرد -

جدول - ا: شاخصهاى توصيفى (ميانكين و انحر اف استاندارد) در دو كروه مورد مطالعه

ميانكين (انحر اف استاندارد) مود مطه

\begin{tabular}{|c|c|c|c|}
\hline $\begin{array}{c}1 . \\
\wedge / 9 \Delta\end{array}$ & $\begin{array}{l}r V \\
r Q / V .\end{array}$ & نوجوجا نوانان بادى & راهبردهاى مقابلهاى مسألهمدار \\
\hline$Q / \Delta r$ & 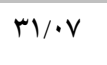 & 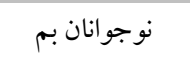 & راهبردهاى مقابلهاى هيجانمدار \\
\hline $11 / 94$ & $r \cdot r r$ & 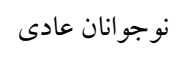 & \\
\hline$|r /| \mid$ & $\Delta N / V Y$ & 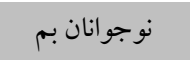 & اميد به آينده \\
\hline $1 Y / \cdot 9$ & $q \pi / I V$ & نوجوانان عادى & \\
\hline IY/FY & $F F / v q$ & 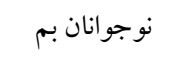 & شاد كامى \\
\hline$I T / F Y$ & $\Delta 9 / \cdot \Delta$ & نوجو انان عادى & \\
\hline
\end{tabular}


جند متغيره جهت تجزيه و تحليل دادههاى اين تحقيق

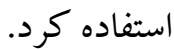
بهعلاوه، قبل از تحليل واريانس جندمتغيره براى تعيين

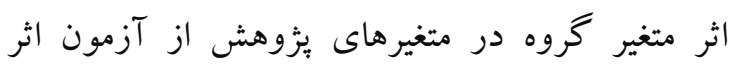
لامبداى ويلكز و اثر بيلايى استفاده شده است؛ كه نسبت F براى هر دو آزمون • 1 19/19 به دست آمد كه در سطح (P<0/05) معنادار بو د.

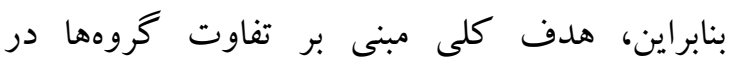
متغيرهاى موردمطالعه مثبت است؛ يعنى دو گروه مورد مردي مطالعه در تركيب متغيرهاى مورد نظر تفاوت معنادارى موردي

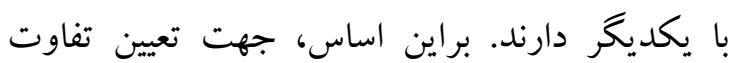
كروهها در كليهى متغيرها به صورت جداگانه از نتايج تحليل واريانس جند متغيره استفاده شده است. با توجه به نتايج تحليل واريانس جندمتغييره، دو گروه مورد مطالعه در كاربرد راهبردهاى مسالهمدار باهم

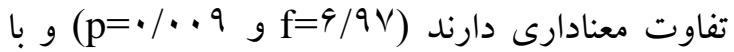
توجه به ميانگين دو گروه در جدول ا هنين استباط

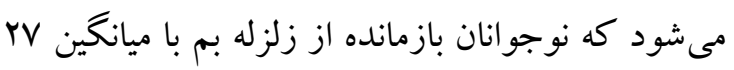

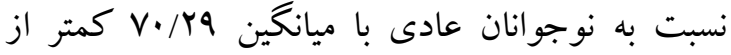
راهبردهاى مقابلهاى مسالهمدار استفاده مى كنند اما نتايج

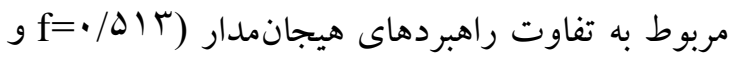
(p=•/FVF علاوه نتايج تحليل واريانس جندمتغيره نشان داد كه دو كروه مورد مطالعه از نظر ميزان شاد كامى باهم تفاوت

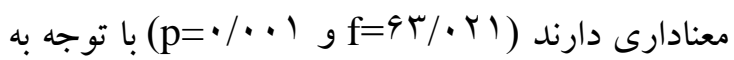
دادههاى جدول او ميانگين VQ/FF دو گروه مشخص كرديد نوجوانان بازمانده از زلزله بم از شادكامى إنى كمترى نسبت به نوجو انان عادى برخوردارند. هم جنين، بردئ تفاوت معنادارى بين دو گروه در ميزان اميد به آينده

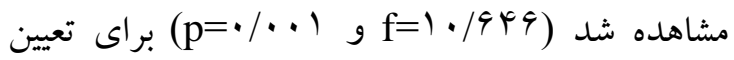
جهت تفاوت دو گروه نيز از دادهاى جدول الستفاده
با توجه به يافتههاى جدول ا مىتوان كفت كه گروه نوجوانان بازمانده از زلزلهى بم در مقياسهاى اميد به آينده، شاد كامى و همجِنين راهبردهاى مقابلهاى مسأله -

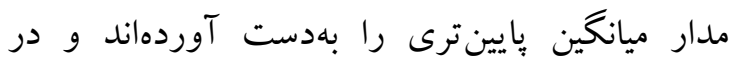
راهبردهاى مقابلهاى هيجانمدار با اندكى تفاوت ميانگين بالاترى را به خود اختصاص دادهاند. امّا استنتاج تفاوت معنادار بين دو گرووه در اين متغيرها مستلزم به كارگيرى آزمون MANOVA است كه زمينه را براى فهم اين تفاوت روشن خواهد كرد. لازم به ذكر است كه قبل از انجام تحليل واريانس،

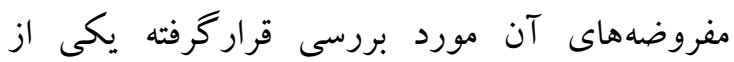
مفروضههاى آن آزمون M باكس است كه برابرى ماتريس كواريانس در دو گروه مورد مطالعه را نشان مىدهد. آزمون M باكس در اين ئزوهش

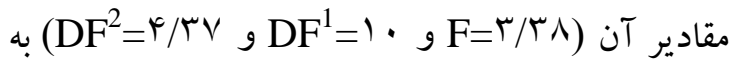
دست آمدهاست، بنابراين اين مفروضه در سطح محقق نشده است. امّا از آنجايى تعداد دادهها زياد است بنابراين، محقق نشدن اين بيش فرض خللى را به وجود نمى آورد. همجنين آزمون لون كه همخنى واريانسها را نشان مىدهد در در مقادير

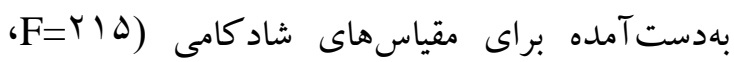
، $\mathrm{F}=F r \Delta\left(\mathrm{DF}^{2}=r F V, \mathrm{DF}^{1}=1\right.$

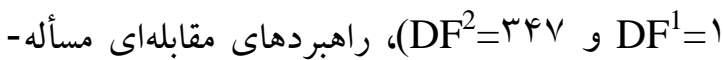

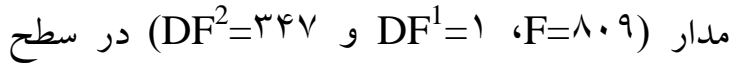
(P< برابرى واريانس ها محقق شده است؛ اما اين ييشفرض براى راهبردهاى مقابلهاى هيجانمدار (DF $\left.{ }^{2}=r Y V, ~ D F^{1}=1 \quad 6 \mathrm{~F}=V / 9 \wedge \Delta\right)$

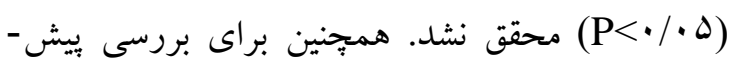
فرض همبستكى متغيرهاى مورد مطالعه از آزمون

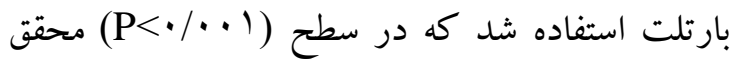
كرديد (X) 
با توجه به نتايج تجزيه و تحليل دادهها مشخص گرديد

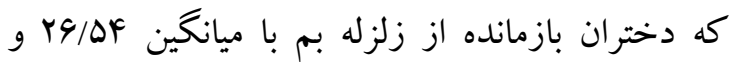

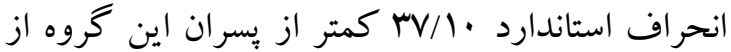
راهبردهاى مسالهمدار و بيشتر از راهبردهاى هيجانمدار

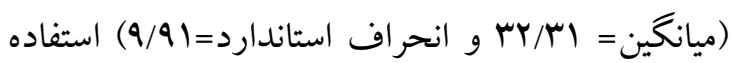
مى كنند. بعلاوه نتايج نشان مىدهد كه بين دو گروه از

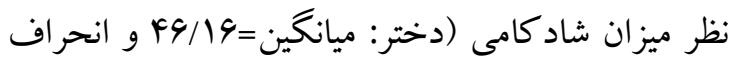

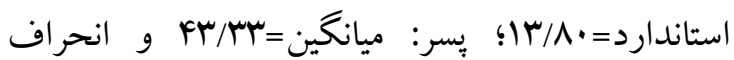
استاندارد=19V/· (1) تفاوت معنىدارى وجود ندارد. همجنين پِران نسبت به دختران بازمانده با ميانگين

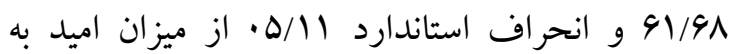
آينده بيشترى برخوردارند. براى بررسى تفاوتهاى جنسيتى در استفاده از راهبردهاى مقابلهاى از آزمون لامبداى ويلكز استفاده

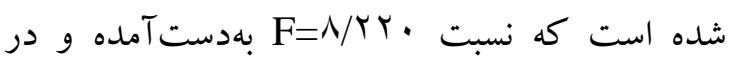
سطح (ه • > P Pعنادار است. هم جنين براى بررسى استفاده از راهبردهاى مقابلهاى بر اساس جنسيت از آزمون تحليل واريانس جند متغيره استفاده شد (جدول
شد كه با توجه به ميانكين VY/OA نشان مىدهد ميزان

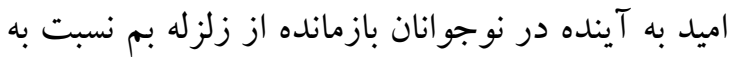
نوجوانان عادى كمتر است. جهت بررسى تفاوت هاى جنسيتى در متغير راهبردهاى مقابلهاى مورد مطالعه نيز از آزمون تحليل واريانس جهند متغيره استفاده شده است. قابل ذكر است كه قبل از انجام آزمون تحليل واريانس جند متغيره، بيش فرض هاى آن به وسيلهى آزمونهاى M باكس و لون لون مورد

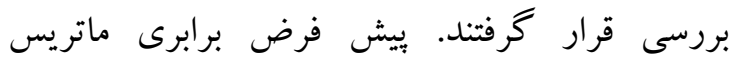
كواريانس با استفاده از آزمون M باكس با توجه بـ به بركي

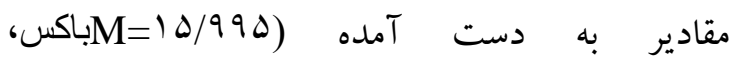
$\left(\mathrm{DF}^{2}=r / r \Delta \cdot \mathrm{DF}^{1}=r \quad \mathrm{~F}=\Delta / r \Delta\right)$ محقق نشده است. همجنين براى بررسى (P<0/05) مفروضهى برابرى واريانس خطاى متغيرها از آزمون

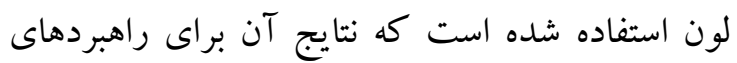

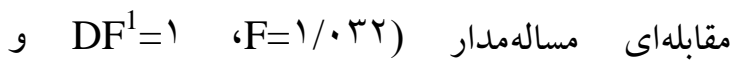
$\left(\mathrm{DF}^{2}=\mid\right.$ و براى راهبردهاى مقابلهاى هيجانمدار

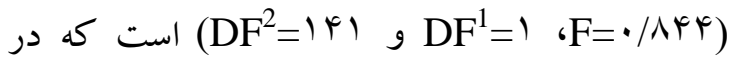
سطح (ه P P P اين مفروضه محقق شده است. بهعلاوه، اطلاعات توصيفى متغيرهاى مورد مطالعه به شرح زير است.

جدول-r: نتايج تحليل واريانس جند متغيره

\begin{tabular}{|c|c|c|c|c|c|c|}
\hline Sig & $\mathbf{F}$ & جذوروات & $\overline{\text { DF }}$ & مجذورات مجموع & متغير ها & \\
\hline$\cdot 1090$ & ( & MT/MaA & 1 & MT/MGA & راهبر دهاى مقابله اى مسأله مدار & جنسيت \\
\hline$\cdot / 1 \cdot 9$ & $r / 9 \cdot F$ & $r m / F q 1$ & 1 & $r r r / F q 1$ & راهبردهاى مقابله اى هيجان مدار & \\
\hline- & - & $1 \cdot \cdot / \Delta r r$ & $|f|$ & IFIVT/GTO & راهبردهاى مقابله اى مسأله مدار & خطا \\
\hline- & - & $199 / 994$ & $|F|$ & ITGFY/GGT & راهبردهاى مقابله اى هيجان مدار & \\
\hline
\end{tabular}


به منظور بررسى تفاوت بين دختران و وِيسران بازمانده از

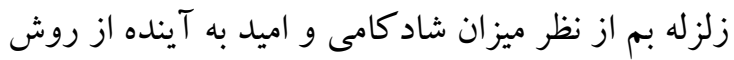
T

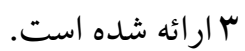

با توجه به معنادار بودن آزمون لامبداى ويلكز در سطح

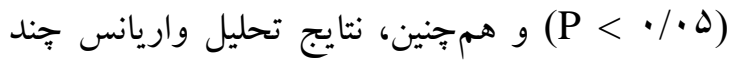

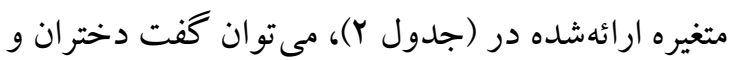

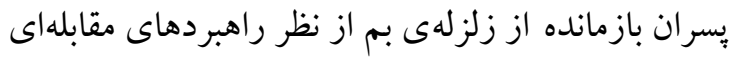

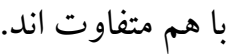

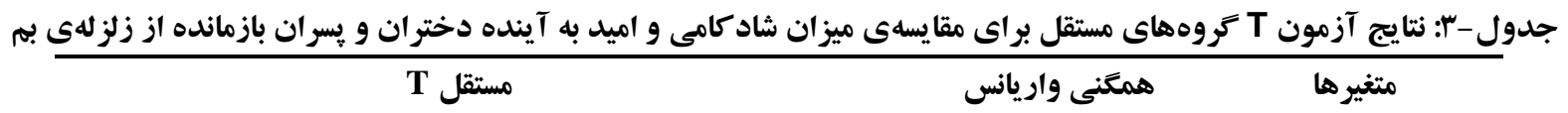

كروه هانو

\begin{tabular}{|c|c|c|c|c|c|c|c|}
\hline خطاى استاندارد & يانغين & ${ }^{\mathrm{D}}$ & $\begin{array}{l}\mathrm{Si} \\
\mathrm{g}\end{array}$ & $\mathrm{T}$ & Sig & $\mathrm{F}$ & \\
\hline \multirow[t]{2}{*}{$Y / \cdot V$} & Y/AY & 1 & If & $1 / \mu^{4}$ &.$/ \cdot F$ & $r / \cdot \Delta r$ & شاد كامى \\
\hline & & $\cdot / \mathrm{V} \Delta$ & 1 & & & & \\
\hline \multirow[t]{2}{*}{$r / I F$} & $-\Delta / N$. & . & If & $-r / 90$ &.$/ .1$ & $9 / 1 r$ & اميد به آينده \\
\hline & & .1 .9 & 1 & & & & \\
\hline
\end{tabular}

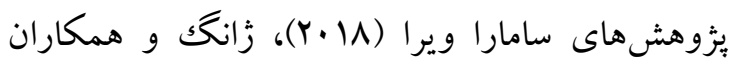
(Y.1.) و نعيم و آنيلا (Y.|F) كه اظهار داشتند راهبردهاى مقابلهاى در افرادى كه با فاجعه روبرو بودهـ-

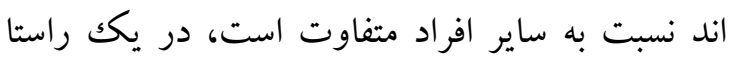

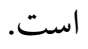
اين يافتها نشان مىدهند افرادى كه تحت استرس بيشتر بودهاند از راهبردهاى مقابلهاى كمتر ساز گارانه استفاده

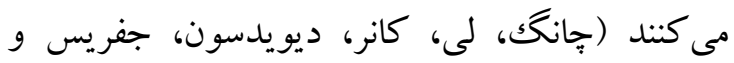
لاى، ...Y). از سوى ديخر، نوجوانان بازمانده از زلزله ى بم با نوجوانان عادى در راهبردهاى مقابلهاى هيجان -

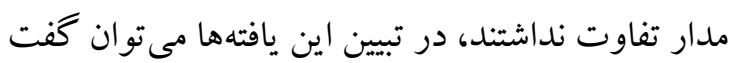
كه متغيرهاى مختلفى در انتخاب نوع راهبرهاى مقابله اي مؤثر هستند. عواملى نظير عقايد فرد در مورد منبع كنترل، عزت نفس فرد، گرايش به نوروزها و و حمايت

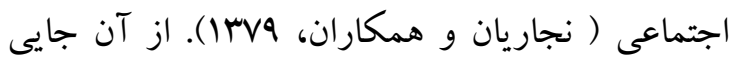
كه اين عوامل در تحقيق لحاظ نشدهاند بنابراين نوجوانان بازمانده و نوجوانان عادى از لحاظ اين
همانكونه كه جدول-r مشاهده مىشود

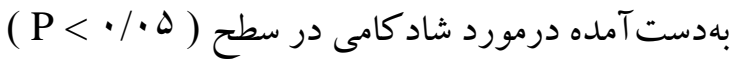
معنى دار نمىباشد. يعنى بين دو گرووه دختر و پِّر بازمانده از زلزلهى بم از نظر ميزان شادكامى تفاوت لتهى معنادارى وجود ندارد. همجينين T بهدست آمده بين دو

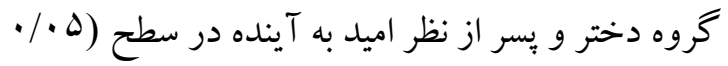

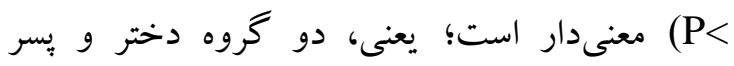
بازمانده از زلزلهى بم از نظر ميزان اميد به آينده با هم

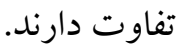

\section{بحث و نتيجه گيرى}

هدف مطالعهى حاضر، مقايسهى راهبردهاى مقابلهاى، شاد كامى و اميد به آينده در نوجو انان بازمانده از زلزله -

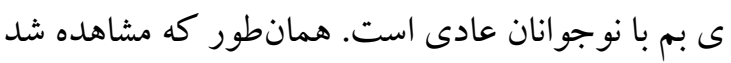
يافتهاى اين يثزوهش نشاندهنده تفاوت معنادار در راهبردهاى مقابلهاى مسالهمدار در بين دو گرّوه مورد مطالعه بود، درحالى كه در راهبردهاى مقابلهاى هيجانمدار تفاوت معنادارى ديده نشد. اين يافته با نتايج 
بهعلاوه، مشخص گرديد كه نوجوانان بازمانده از زلزلهى بم از نظر ميزان اميد به آينده با نوجوانان عادى بهى بهري تفاوت دارند؛ كه اين يافته با نتايج بيزوهش هاى نجاريان و همكاران (IrV9)، سروش و و همكاران (بهץ|) و تر (1991) كه معتقدند روبرو شدن با فجايع،

باعث افزايش ناميدى در افراد مىشود، همسو است. در تبيين اين يافتهها مىتوان كفت كه اين نوجوانان در

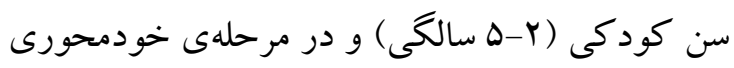
رشد با زلزله و بيامدهاى حاصل از آن روبهرو شدهاند. در واقع سن ذكر شده، دورهاى است كه كود كان خود را در انجام هر كارى توانا مىبينند و مىخواهند شرايط

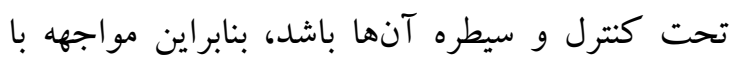
زلزله در اين مرحله از رشد بر ديدكاه آنها در مورد خودشان و دنيا تأثيرات منفىاى گذاشته است. از طرفى ركى ديخر اين ناميدى از آنجايى آغاز مىشود كه مدام اتفاقات منفى رخ مىدهد يا اين كه اتفاقات مثبت رخخ

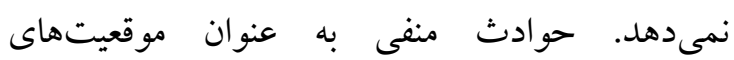
برانگيزانندهى ناميدى عمل مى كنند. درنتيجه فرد بر اثر نااميدى به شدت غيرفعال شده، نمى تواند موقعيتهاى

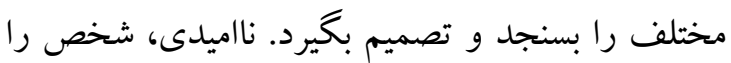
به سرعت در هم مىشكند و او را در برابر عوامل فشارزا، بىدفاع و كرفتار مى كند و با كذشت زمت زمان شخص تمام اميد خود را از دست مىدهد (عليزاده

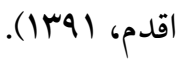
بهعلاوه ميان دختران و پِر ان بازمانده از زلزلهى بم در راهبردهاى مقابلهاى تفاوتهاى مشاهده شد؛ كه اين يافته با يُزوهش هاى داعى يور و بيانزاده (IrVNA)، بردبار

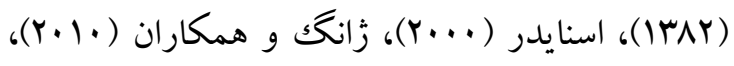

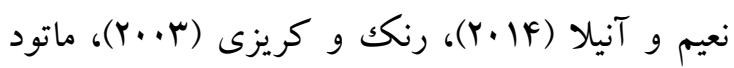
كه به تفاوت كاربرد راهبردهاى مقابلهاى (Y.F) دختران و بِران كروههاى آسيبديده يرداختهاند، همسو است. اين نتايج، بيان مى كنند كه دختران بيشتر از
متغيرها به خوبى همتا نشدهاند و ممكن است اين عوامل در يافتهاى اين بثزوهش تأثير كذار بوده باشند.

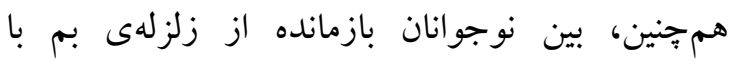

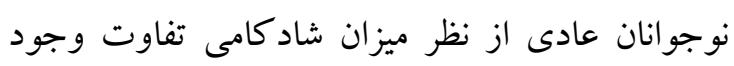

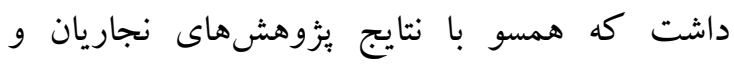

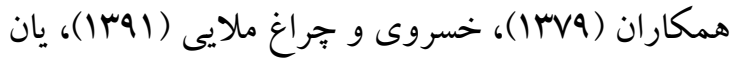

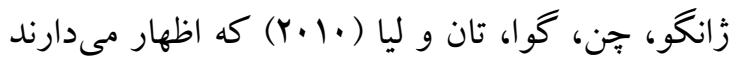
حوادث فشارزا مى تو انند بر ميزان شاد كامى افراد قربانى تونى تأثير گذار باشد، است. بر اساس نظريهى بيوشيميايى مغز جنين فرض مى شود كه مواجهه انسانها با فشارزاهاى شديد و غيرقابل كنترل

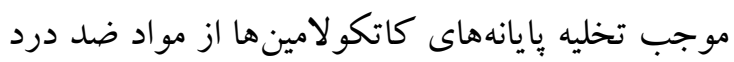
و تسكين دهنده مىشود كه اين تخليهى كاتكولامينها سبب بروز علائم PTSD از جمله كاهش انخيزش و افت فعاليت مىشود. بهعلاوه، به نظر مىرسد كه مسيرهاى عصبى و مغزى در مواجهه با حوادث فشارزا

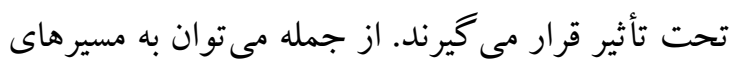

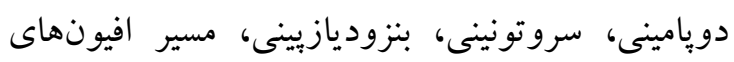
درونزاى مغزى و محور غدهى فوق كليه - هييوفيز هييو تالاموس اشاره كرد كه ترشح مواد شيميايى درون مغزى (انتقالدهندهاى عصبى) از جمله سروتونين را

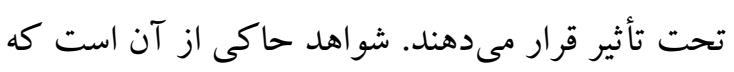
پِ از مو اجههى حيو انات با فشارهايى كه نمى تو انند از آنها بكريزند، سروتونين بدن آنها كاهش مىيابد و و

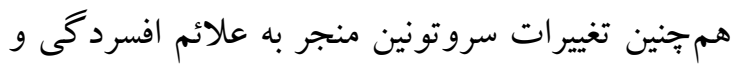
عدم لذت از زندگى و نيز بى علاقكى به ايجاد رابطه با تهيرات سايرين در افراد مبتلا به PTSD مىشود (كيليين و

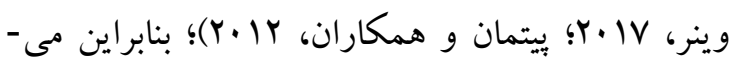
توان كفت كه اين تغييرات در انتقال دهندههاى عصبى ونى و سيستمهاى مغزى بر ميزان شادكامى افراد تأثير گذار

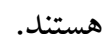


كنترل افكارشان، خوشبختى ذهنى و شاد كامىشان را

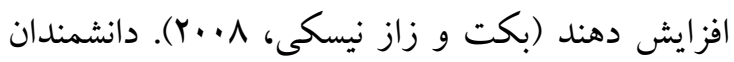
عصبشناسى معتقدند كه تر كيبات شيميايى و كار كرد مغز كسانى كه داراى خلق شاد، افسرده، خشمخين و... هستند با هم تفاوت دارد و شاد كامى به فعاليت منطقه جلويى قشر مخ مربوط است (كار، ·...r؛ به نقل از

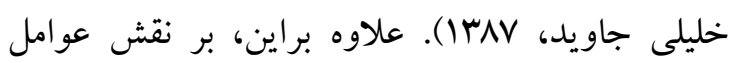
شخصيتى، جامعهشناسى و زمينهاى نيز در شادكامى

$$
\text { تأكيد شده است (هالر و هادلر، 9. ..ب). }
$$

بهعلاوه، در اين يزوهش نشان داده شد كه ميزان اميد به آينده دختران و بسران بازمانده از زلزلهى بم بـ با هم متفاوت است و دختران بازمانده از زلزله بم ميزان اميد به آينده كمترى نسبت به يسران دارند. اين يافته با نتايج

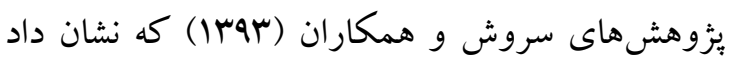
حوادث فشارزا بر روى ميزان اميد به آينده زنان تأثير

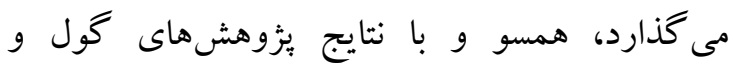

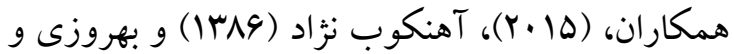
همكاران (ITVNA) كه نشان دادند ميزان اميد به آينده در دختران تحت تأثير حوادث فشارزا بيشتر از پسران است و همجنين با نتايج عبدالهى (1) (I) و صيادى و جوان

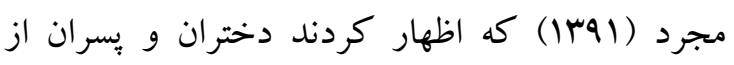
لحاظ ميزان اميد به آينده تفاوتى ندارند، ناهمسو است.

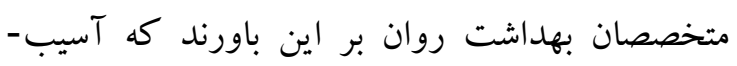

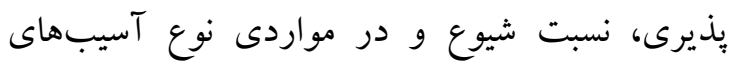
روانى برحسب جنسيت، متفاوت است. همجنين،

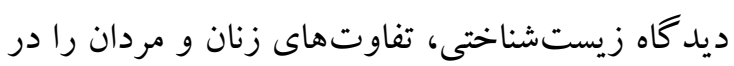
جهارجوب آسيب يذيرى بيشتر زنان در مراحل مختلف زندگىشان و در فرهنگگهاى گوناكون قابل مشاهده

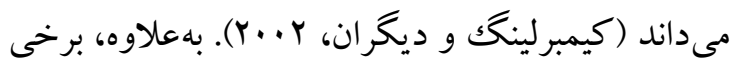
نيز اين تفاوت در واكنش مردان را ازيككطرف ناشى از عوامل شناختى و نحوهى تفسير آنها از رويداد و از

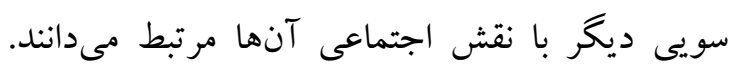

راهبردهاى مقابلهاى هيجانمدار و پِران از راهبردهاى مقابلهاى مسأله مدار استفاده مى كنند. با توجه به اين يافتها مىتوان گفت كه مردان بر حسب ويز گیىهاى جنسيتى مستقيماً و فعالانه بر رويداد يا مسأله تمركز دارند و زنان بيشتر از مردان به تجارب هيجانى خود توجه و واكنش نشان مىدهند (ندائى، سوب|). همجنين ويزگى ذاتى زنان و جامعهيذيرى مبتنى بر هيجان ايجاب مى كند كه به جاى درگيرى در موقعيت به ديه بازسازى هيجانى و تنظيم آن اقدام كنند. جِنانجه طبق اصل يادگيرى و تئورى زيستى زنان با جامعهيذيرى جنسى ويزه و مبناى زيستى متفاوت عمل مى كنند. در

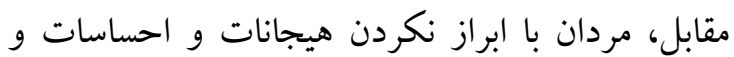

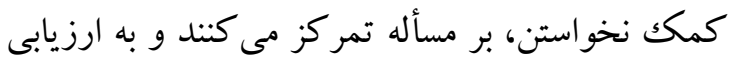

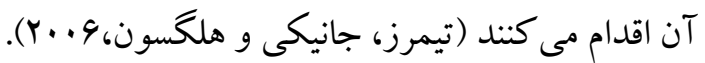
همجنين مشخص گرديد كه دختران و يسران بازمانده از زلزلهى بم از نظر ميزان شادكامى با هم تفاوتى لتى ندارند؛ كه اين يافته با نتايج شيخ مونسى، ضرغامى،

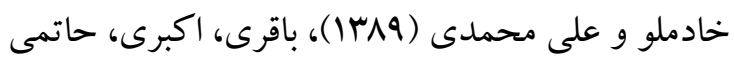

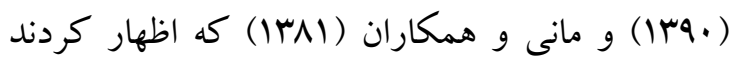
شادى تنها حالتى درونى نيست و با مشخصات دمو گر افيك رابطهاى ندارد، همسو است و با نتايج وود

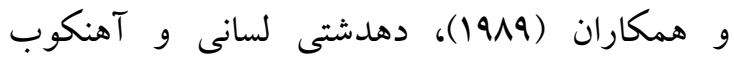

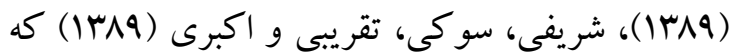
شادى را در زنان بيشتر از مردان ارزيابى كردند،

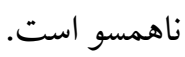

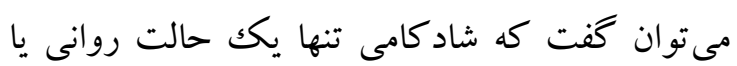
ذهنى نيست بلكه به وضعيت مغز نيز ارتباط دارد. در نظريههاى شناختى اعتقاد بر اين است كه افراد شاد كام رويدادهاى فرهنگى مطلوب بيشترى را تجربه مى كنند و همجنين رويدادهاى خنثى را به صورت مثبت و

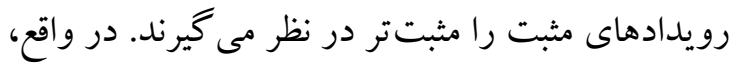

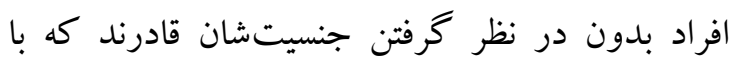


بازماندگان از اين زلزله مورد استفاده روانشناسان، مدد كاران و تمام متصديان اين حرفه قرار گيرد.

\section{References}

Abdollahi, M. (2010). Sociological Explanation of Hope for the Future. Quarterly Journal of Social Science Education, 49, 34-41.(Persian)

Ahankoubnejad, M. R. (2008). Survey of relationship between individual characteristic and out looking hope in youth of Ahwaz city. Univercity of Tabriz, Master's thesis. (Persian)

Alipour, A., Hashemi, T., Babapour, J., \& Tousi, F. (2010). Relationship between Coping Strategies and Happiness among University Students. Journal of Scientific and Research in Psychology Tabriz University, 5(18). (Persian)

Alizadeh Aghdam, M. B. (2013). A study of hope in the future among students and It's affecting factors. Journal of Applied Sociology, 48(4), 189-206. (Persian)

Argyle, M., Martin, M., \& Lu, L. (2001). spielberge. sarasonl testing for stress and happiness: the role of social and cognitive factors. Stress and Emotion, 173-187.

Baqeri, F., Akbarizadeh, F., \& Hatami, H. R. (2011).

The relationship between spiritual intelligence and happiness and demographic variables in nurses of Fatemeh Alzahra and Bennet Alhodi Hospitals in Bushehr. Bimonthly Iranian South Medical Journal, 14(4), 265-263. (Persian)

Bedriye, A. k. (2014). Determination and Evaluation of Effects of Earthquake on School Age Children's (6-12 Years Old) behaviors. Procedia - Social and Behavioral Sciences, 152, 845-851.

Behrouzi, N., \& Mohammadi, N. (1999). The Relationship between the Meaning of Life and Hope in Shiraz University Students. Proceedings of the 4th Students' Mental Health Seminar.(Persian)

Bekhet, A. K., Zauszniewski, J. A., \& Nakhla, W. E. (2008). Happiness: Theoretical and empirical considerations. In Nursing Forum, 43 (1), 12-23.

Bordbar, M. (2003). Comparison of coping strategies in successful and unsuccessful students. Univercity of Shiraz, Master's thesis. (Persian)

Burns, G. W. (2010). Happiness, healing, enhancement. Published by john wiley \& sons. Hobken, New Jersey.
بهعبارتى ديخر، مىتوان گفت در هنگام بروز يكك

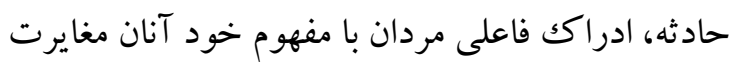
دارد در نتيجه كوشش مى كنند تا با تغيير مسير افكارشان تعارض را كاهش دهند. جِنين فرآيندى به توقف بروز نشانها در مردان و سهولت بيشتر در نمايش نشانها در زنان منجر مىشود (ساكس و ولف، 1999). بهعلاوه، نشان داده شده است كه اميدوارى با مقابله مؤثر و بهزيستى بهتر رابطه دارد و تعديل كنندهى رابطه ى بين افسردگى و رويدادهاى ناخوشايند زندگى است ونى

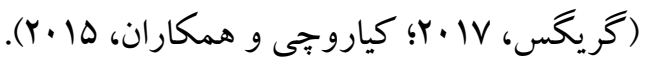
در مجموع بر اساس اين يافتها مىتوان كفت با توجه

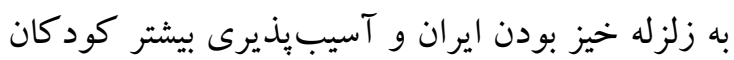

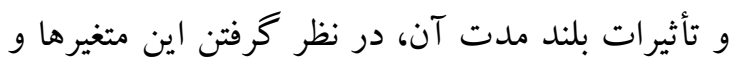
توجه به آنها در مورد افراد بازمانده از زلزله مىتواند نتايج مثبت و ارزندهاى داشته باشد و با انجام دادن

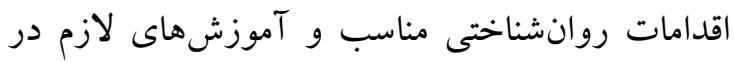
زمينه راهبردهاى مقابلهاى مىتوان ميزان آسيب بذيرى افراد زلزلهزده را به ميزان قابل توجهى كاهش داد. با توجه به اينكه هر بزوهشى محدوديتهايى دارد

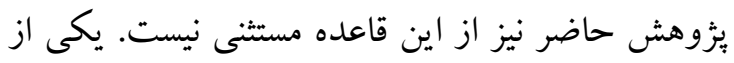

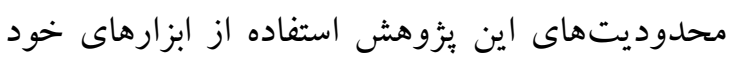

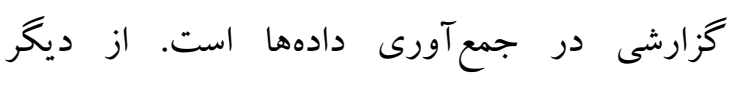
محدوديتهاى اين ئزوهش عدم كنترل متغييرهايى مانند وضعيت اجتماعى-|قتصادى، ميزان تحصيلات والدين، ويز گىىهاى شخصيتى و ميزان مو اجهه با فاجعه

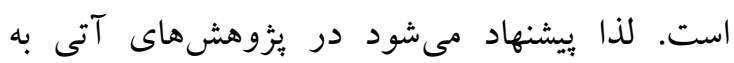
بررسى نقش ميانجى گرى اين متغيرها برداخته شود.

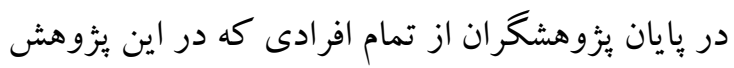
مشار كت داشتهاند و صبور انه با آنها همكارى كردهاند

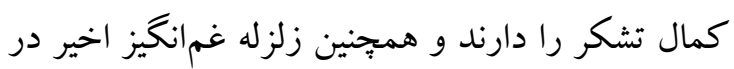

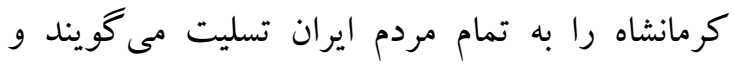
اميدوارند كه يافتهاى اين بزّوهش جهت بهبود حال 
Calvo, R., Arcaya, M., Baum, C. F., Lowe, S. R., \& Waters, M. c. (2015) Happily Ever After? Preand-Post Disaster Determinants of Happiness among Survivors of Hurricane Katrina. J Happiness Stud, 16(2), 427-442.

Chang, C. M., Lee, L. C., Connor, K. M., Davidson, J. R., Jeffries, K., \& Lai, T. J. (2003). Posttraumatic distress and coping strategies among rescue workers after an earthquake. The Journal of nervous and mental disease, 191(6), 391-398.

Ciarrochi, J., Parker, P., Kashdan, T. B., Heaven, P. C. L., \& Barkus, E. (2015). Hope and emotional well-being: A six-year study to distinguish antecedents, correlates, and consequences. The Journal of Positive Psychology, 1-13.

Coyne, J. C., \& Racioppo, M. W. (2000). Never the twain shall meet? Closing the gap between coping research and clinical intervention research', American Psychologist, 55(6), 65564.

Daipour, P. (1999). Preliminary survey of adolescents coping scale in Tehran students, Tehran psychiatric institute, Master's thesis. (Persian)

Datar, A., Liu, J., Linnemayr, S., \& Stecher, C. (2013). The impact of natural disasters on child health and investments in rural India. Social Science \& Medicine, 76, 83-91.

Dehdashti Lesani, M., \& Ahankoubnejad, M. (2010). Evaluation of happiness in native and nonnative students of Shahid Chamran University in Ahwaz and its relation with academic performance.(Persian)

Diener, E., Lucas, R. E., \& Scollon, C. N. (2006). Beyond the hedonic treadmill: revising the adaptation theory of well-being. American Psychologist, 61(4), 305.

Gilpin, N. W., \& Weiner, J. L. (2017). Neurobiology of comorbid post-traumatic stress disorder and alcohol-use disorder. Genes Brain Behavior, 16(1), 15-43.

Griggs, S. (2017). Hope and Mental Health in Young Adult College Students: An Integrative Review. Journal of Psychosocial Nursing and Mental Health Services, 55(2), 28-35.

Gull, M., \& Nizami, N. (2015). Gender Difference on Hope \& Psychological Well-being among the Parents of Differently Abled Children. The International Joumal of Humanities \& Social Studies, 3(9), 1-4.
Haller, M., Hadler, M. (2006). How social relations and structures can produce happiness and unhappiness: an intemational comparative analysis, social Indi cators Research.

Hashemi, T., Aliloo, M. M., Poursharifi, H., Bayrami, M., \& Nemati Sogolitappeh, F. (2013). The role of personality characteristics and coping strategies in self-care of patients with Type2 diabetes. Joumal of Clinical Psychology, 5(2), 89-99. (Persian)

Hosseini, F., Salimi, T., Nadi- Sakhvidi, M., \& Ahmadi, E. (2015). Happiness in Extems in Shahid Sadoughi University of Medical Sciences in 2012, J Shahid Sadoughi Univ Med Sci, 23(2), 1945-52. (Persian)

Kar, N. (2009). Psychological impact of disasters on children: review of assessment and interventions. World j pediatr, 5(1), 5-11.

Kelberer, J. A, Kraines, M. A., \& Wells, T. T. (2018). Optimism, hope, and attention for emotional stimuli. Personality and Individual Differences, 124, 84-90.

Kermani, Z., Khodpanahi, M., \& Heidari, M. (2011). Psychometrics features of the Snyder hope scale. Joumal of Applied Psychology, 5(3), 723. (Persian)

Khalili Javaidharis, F. (2009). The relationship between psychological hardiness and social support with happiness in high school students. University of Tabriz, Master's thesis. (Persian)

Khosravi, Z., \& Cheraq Mollaii, L. (2012). Social commitment, happiness and mental health among high school and university students a comparative study emphasizing gender. Quarterly women study, 10(1), 7-35.(Persian)

Kiafar, M. S., Kareshki, H., \& Hashemi, F. (2014). The role of hope components and optimism on academic motivation of graduate students of Ferdowsi University and Mashhad University of Medical Science. Iranian Joumal of Medical Education, 14(6), 517-526. (Persian)

Kimberling, R., Ouimette, P., \& Wolfe, J. (2002). Gender and PTSD. New York: Guilford Press. Lasting full fillment. NewYork: free press.

Lack, C.W., \& Sullivan, M.A. (2008). Attributions, coping, and exposure as predictors of long-term postraumatic distress in tornado-exposed children. Journal of Loss \& Trauma, 13(1), 7284. 
Lazarus, R. S., \& Folkman, S. (1984). The concept of coping in stress, appraisal, and coping. New York: Spinger.

Li, N., Wang, Y., Yu, L., \& Et al. (2017). Long-term effects of earthquake experience of young persons on cardiovascular disease risk factors. Arch Med Sci, 13(1), 75-81.

Mahmood Aliloo, M., Bakhshipour, A., Esmaeili, M., \&, Toofan Tabrizi, M. (2010). Personality traits and coping styles in patient with essential hypertension. Medical Joumal of Tabriz University of Medical Science, 23(2), 61-66. (Persian)

Mani, A., Tahmasebi, S., \& Hadian Fard, H. (2002). Study of vitality in a group of students in Shiraz University, Iranian Congress of Psychology. Tarbiat Moalem University. (Persian)

Matud, M. P. (2004).Gender differences in stress and coping styles. Personality and individual Differences, 37, 1415-1401.

Naeem, A., \& Anila, K. (2014). Coping strategies as a predictors of psychological distress and post traumatic growth among flood affected individuals. Joumal of Alcholism \& Drug dependence.

Najafi, M., Dehshiri, Gh., Dabiri, S., Sheikhi, M., \& Jafari, N. (2013). Psychometric properties of Farsi version of the Oxford happiness questionnaire among college students. Training Measurement, 10(3), 55-73. (Persian)

Najjarian, B., \& Barati Sade, F. (2000). The psychological consequences of catastrophes. Tehran, Masir.(Persian)

Nedaii, A. (2014). Study of gender differences in coping strategies in marital adjustment and its comparison. Journal of Women's Studies Sociological and Psychological, 12(3). 141-167. (Persian)

Nejati, H. (2009). Child psychology, Bikaran, Tehran, 10. (Persian)

Nemati Sogolitappeh, F. (2012). The role of personality traits in self-care behaviors and treatment outcomes in patients with type 2 diabetes due to the moderating role of coping styles. University of Tabriz, Phd thesis. (Persian)

Peterson, c. (2000). The future of optimism. American psychologist, 55, 35-44.

Pitman, R. K., Rasmusson, A. M., Koenen, K. C., \& et al. (2012). Biological Studies of Postraumatic
Stress Disorder. Nat Rev Neurosci, 13(11), 769 787.

Poursadeq, Z. (2013). The effectiveness of group counseling based on rational-emotionalbehavioral approach on emotional regulation and coping strategies for mothers of children with cerebral palsy. University of Tabriz, Master's thesis. (Persian)

Rank, K., \& Creasey, G. (2003).The relationship of gender identify and coping strategies in late adolescents. Jomal of adolescents. 159-198.

Salcioglu, E., \& Basoglu, M. (2008). Psychological effects of earthquakes in children: prospects for brief behavioral treatment. World J Pediatr, 4(3), 165-72.

Samaraweera, H. U. S. (2018). Coping strategies identified and used by victims of flood disaster in Kolonnawa area: An analysis from a social work perspective. Procedia Engineering, 212, 675-682.

Saxe, G., \& Wolfe, J. (1999). Gender and posttraumatic stress disorder. In Saigh P. A., Bremmer J.D., (editors). Post-traumatic Stress Disorder. Allyn and Boston, Mass: Bacon.

Seghatizadeh Sorkhab, M. (2011). Comparison of defense mechanisms and coping strategies in depressed, anxious, stressed, mixed and normal individuals. Univercity of Tabriz, Master's thesis. (Persian)

Seyyadi, A., \& Javanmojarad, N. (2012). Evaluation of hope among students, Proceedings of the Sixth Conference of Gilan University student's mental health. (Persian)

Sharifi, Kh., Sooky, Z., Taghamobi, Z, \& Akbari, H. (2010). Happiness and its related factors among the students of Kashan University of medical sciences in 2006-7. Feyz, Joumal of Kashan University of Medical Sciences, 14(1), 62-69. (Persian)

Sheikhmoonesi, F.,Zarghami, M., Khademloo, M., \& Alimohammadi, M. M. (2013). Happiness and associated demographic factors among medical students of Mazandaran University of Medical Science, 2010. Journal of Mazandaran University of Medical Science, 22(97), 132-137. (Persian)

Snyder, C. R. (2000). Hand book of hope. Sandiego: Academic press swligman, M. E. Authentic happiness. New York: free press. 
Snyder, C. R. (2002). Hope theory: Rainbows in the mind. Psychological inquiry, 13(4), 249.

Snyder, C. R., Harris, C., Anderson, J. R., Holleran, S. A., Irving, L. M., Sigmon, S. T., \& et al. (1991). The will and the ways: development and validation of an individual-differences measure of hope. Joumal of personality and social psychology, 60(4), 570.

Soroush, M., Hejazi, E., Shoakazemi, M., \& Gheranpayeh, L. (2015). Psychological characteristics and hope in women with breast cancer. Iranian Journal of Breast Disease, 7(4), 52-63. (Persian)

Spinhoven. P., Elzinga, B. M., Giltay, E., \& Penninx, B. W. J. H. (2015). Anxious or Depressed and Still Happy? PLoS One, 10(10), e0139912.

Venning, A., Kettler, L., Zajac, I., Wilson, A., \& Eliott, J. (2011). Is Hope or Mental Illness a Stronger Predictor of Mental Health? International Joumal of Mental Health Promotion, 13(2), 32-39.

Wang, W., Fu, W., Wu, J., \& et al. (2012). Prevalence of PTSD and Depression among Junior Middle
School Students in a Rural Town Far from the Epicenter of the Wenchuan Earthquake in China. PLoS One, 7(7), e41665.

Wolf, J., \& charney, D. S. (1991). Use of neuropsychological assessment in posttraumatic stress disorder. Psychological assessment, 3(4), 573-580.

Wood, W., Rhodes, N., \& Whelan, M. (1989). Sex differences in positive well-being: A consideration of emotional style and marital status. Psychological Bulletin, 106(2), 249.

Zare, B. (2011). Investigating happiness and its effective factors (Case study: Kerman city). Shahid Bahonar University, Master's thesis. (Persian)

Zhang, Y., Kong, F., Wang, L., Chen, H., Gao, X., Tan, X., \& Liu, Y. (2010). Mental health and coping styles of children and adolescent survivors one year after the 2008 Chinese earthquake. Children and Youth Services Review, 32(10), 1403-1409. 